\title{
Perceived Organization Support Towards Employee Engagement and The Impact of Employee Job Satisfaction
}

\author{
Upik Sri Sulistyawati ${ }^{*}$, Dedi Sufriadi ${ }^{2}$ \\ ${ }^{1}$ Management Study Program, STIE Sabang Banda Aceh 2, Banda Aceh, Indonesia \\ ${ }^{2}$ Information Systems Study Program, STMIK Indonesia Banda Aceh, Banda Aceh, Indonesia
}

\author{
A R T I C L E I N F O \\ Article history: \\ Received 18 May 2020 \\ Received in revised form \\ 5 June 2020 \\ Accepted 18 July 2020 \\ Available online 29 August \\ 2020 \\ Keywords: \\ Perceived Organizational \\ Support, Engagement, \\ Performance
}

\section{A B S T R A C T}

This study was to analyze the effect of perceived organizational support on employee engagement and its impact on employee job satisfaction. This type of research is explanatory research with a quantitative approach. Hypothesis testing using the hierarchical regression analysis method with the help of SPSS version 21. The results showed that: there was a positive influence on perceived organizational support on employee engagement. with the result $Z=0.628 ; t=6,096 ; p<0.001$; there is a positive effect of perceived organizational support on employee performance indicated by the result $Y=0.791 ; t=12,022 ; p<0.001$; There is a positive influence on employee engagement on employee performance as indicated by $\mathrm{Y}=0.323 ; \mathrm{t}=2,766 ; \mathrm{p}<0.01$ ); and employee engagement can be proven as a mediating variable on the effect of perceived organizational support on the performance of administrative employees. So, there is an effect of perceived organizational support on employee engagement and its impact on employee job satisfaction. These findings are expected to evaluate employee performance and understand the process of implementing policies for employees.

Copyright (C) Universitas Pendidikan Ganesha. All rights reserved.

\section{Introduction}

Perceived organizational support is defined as employees' perceptions of the organization about how much an organization appreciates the contribution and care for the welfare of its employees (Ariarni \& Afrianty, 2017; Luh et al., 2020; Mursidta, 2017; Pertiwi et al., 2019). Perceived Organizational Support can also be seen as an organizational commitment to employees (Lase et al., 2020; Mujiasih, 2015). If the organization generally appreciates the dedication and loyalty of employees as a form of employee commitment to the organization, the employees generally also pay attention to how committed the organization has to them. (Fatdina, 2015). Employees with a high level of perceived organizational support are more maximal in providing their performance so that perceived organizational support will result in remuneration in the form of a level of engagement with employees or employee engagement (Mufarrikhah et al., 2020; Simatupang \& Salendu, 2019). Organizational support plays a very important role in indicating the company's willingness to pay attention to and reward employee performance in helping the company succeed (Panuju \& Mangundjaya, 2018). So, Perceived organizational support will have a positive impact on employee engagement.

Employee engagement is the spirit of employees at work that occurs because employees direct their energy to work in line with the company's strategic priorities (Afendi et al., 2020; Asih \& Dewi, 2017; Kang et al., 2020; Pringgabayu \& Kusumastuti, 2016). This spirit is formed because employees feel attached to the organization so that it has a positive potential for the organization, namely an increase in income. Factors that influence Employee Engagement include (1) Job resources which refer to the physical, social and organizational aspects of the work that allow workers to meet work demands related to their physical and mental health, (2) Salience of Job re-sources, namely how the worker deals with job demands and fulfills these demands, and (3) personal resource which is a positive self-evaluation that will relate to a person's feelings towards his or her ability to succeed in managing and giving influence the environment 
(Bakker et al., 2014). So, Employee Engagement is an employee's attitude and behavior at work by expressing himself in totality both physically, cognitively, affective, and emotionally. Employees find meaning in work, pride in being part of the organization where they work, working to achieve the overall vision and mission of an organization. Employees will go the extra mile and strive for the above work so that what is expected is achieved in both time and energy. In other words, with Employee Engagement, employees will show their best performance (Fajriah \& Darokah, 2016). Performance is intended as the level of success of the individual as a whole during a certain period in carrying out the task compared to the standard of work results, targets, or targets or criteria that have been determined and have been set together. (Ariarni \& Afrianty, 2017; Sufriadi, 2018).

Perceived Organizational Support has an impact on increasing company commitment, attitudes towards work such as job satisfaction and positive mood job involvement, work performance, the desire to stay in the company, and reduce pressure at work and reduce withdrawal behavior, resulting in an increase in company productivity. The higher the level of perceived organizational support, the level of employee engagement also increases, and conversely the lower the level of perceived organizational support, the lower the level of employee engagement. Perceived positive organizational support from employees will make employees work better by prioritizing commitment to goals, Monitoring their behavior to ensure that what is done is correct and in accordance with the goals to be achieved, and also uses intelligence to make choices on how best to complete a task and making decisions to correct if needed is an indication of high engagement employees. Many studies have been conducted to determine the relationship between Perceived organizational Support, employee engagement, and employee performance.

Research conducted by Fatoni et al., (2018) shows that Perceived organizational support, employee engagement has a significant effect on employee performance, as well as employee engagement and organizational commitment, have a significant effect on OCB, and OCB has a significant direct effect on employee performance. Research conducted by Dai \& Qin, (2016) shows the results of the research show that: first, Perceived organizational support and employee engagement thas a significant positive correlation, perceived organizational support has a positive direct effect on employee engagement employees; second, Perceived organizational Support can also play a role in k employee engagement employees through organizational identification. Research conducted by Iskandar \& Juhana, (2014), it was found that the results of competence and work environment had a simultaneous effect on job satisfaction by 61.3 percent. Ratanjee and Emond (2013) stated that there are 8\% of Indonesian workers who have work engagement, while $15 \%$ are in the category of actively disengaged, which means workers are not only unhappy at work, workers are also disappointed because their needs are not met so they decide to leave. from the company, every day these workers have the potential to ruin what their engaged coworkers achieve. The purpose of this study to analyze the effect of perceived organizational support on employee engagement and its impact on job satisfaction of administrative staff at the Regional General Hospital dr. Zainoel Abidin Banda Aceh.

\section{Methods}

This type of research is explanatory research with a quantitative approach. The population in this study were all employees at the Regional General Hospital dr. Zainoel Abidin Banda Aceh totaling 2,456 people. Sampling using probability sampling techniques with the type of cluster sampling selected by lot from each section or division of 62 people. The questions in this research instrument come from previous research. The questionnaire was filled in by respondents and the results were measured using a Likert scale. The data analysis technique used in this research is descriptive statistical analysis and hierarchical regression analysis. Descriptive Statistical analysis is used to obtain frequency data, percentage, and an average score of respondents' answers for each question item for each variable. Hierarchical Regression Analysis (Ariarni \& Afrianty, 2017) was used to test the influence of employee engagement variable mediation in the relationship between perceived organizational support and employee performance.

\section{Results and Discussions}

Hierarchical Regression Analysis Test Results, this analysis is used to test all research hypotheses. Testing the effect of mediation uses a testing basis that requires testing 3 sets of relationships, namely the relationship between (1) perceived organizational support and employee engagement, (2) perceived organizational support (POS) and employee performance, (3) employee engagement and employee performance. Table 1 presents the results of the hierarchical regression analysis consisting of 3 models: 
Table 1. Results of Hierarchical Regression Analysis for Hypothesis Testing

\begin{tabular}{cccc}
\hline Variable & Model 1 & Model 2 & Model 3 \\
\cline { 2 - 4 } Independent & $\begin{array}{c}\text { Employee Engagement } \\
(\mathrm{Z})\end{array}$ & $\begin{array}{c}\text { Employee } \\
\text { Performance }(\mathrm{Y})\end{array}$ & $\begin{array}{c}\text { Employee } \\
\text { Performance }(\mathrm{Y})\end{array}$ \\
\hline Perceived Organizational & 0.628 & 0.791 & 0.696 \\
Support & & & \\
Adjusted R2 & 0.372 & 0.702 & 0.702 \\
F & 37,164 & 144,539 & 144,539 \\
Employee & 0.218 & 0.237 & 0.323 \\
Engagement & & & 0.732 \\
Adjusted R2 & 0.234 & 0.720 & 0.030 \\
$\Delta$ Adjusted R2 & & 0.030 & 84,102 \\
F & 12,146 & 16.5 & Significant at $\mathrm{p}<.01 ; \mathrm{p}<.001$
\end{tabular}

Source: Researcher Processed Primary Data, 2020

Based on the hierarchical regression test in Table 1, it can be seen that all the hypotheses in this study are supported by the following detailed explanations:

First, Hypothesis 1 (H1) perceived organizational support has a positive and significant effect on employee engagement. Model 1 in table 1 shows that perceived organizational support has a positive and significant effect on employee engagement $(Z=0.628 ; t=6.096 ; p<0.001)$. This means that hypothesis 1 (H1) is supported. Based on the results of hypothesis testing, it can be concluded that perceived organizational support has an influence on employee engagement at the Regional General Hospital dr. Zainoel Abidin Banda Aceh.

Second, Hypothesis 2 (H2) suspects that perceived organizational support has a positive and significant effect on employee performance. Model 2 in table 1 shows that perceived organizational support has a positive and significant effect on employee performance ( $\mathrm{Y}=0.791 ; \mathrm{t}=12.022 ; \mathrm{p}<0.001)$. This means that hypothesis 2 (H2) is supported. Based on the results of hypothesis testing, it can be concluded that perceived organizational support has an influence on the performance of employees at the Regional General Hospital dr. Zainoel Abidin Banda Aceh.

Third, Hypothesis 3 (H3) suspects that employee engagement has a positive and significant effect on employee performance. Model 3 in table 1 shows that employee engagement has a positive and significant effect on employee performance ( $\mathrm{Y}=0.323 ; \mathrm{t}=2.766 ; \mathrm{p}<0.01)$. This means that hypothesis 3 (H3) is supported. The results of hypothesis testing can be concluded that employee engagement has an influence on employee performance at the Regional General Hospital dr. Zainoel Abidin Banda Aceh.

Fourth Based on the results of mediation testing conducted by researchers, it is known that employee engagement mediates the relationship between perceived organizational support and employee performance. Based on the results of the analysis of the effect of mediation, it was found that there was an effect of mediation/mediation on employee engagement in the relationship between perceived organizational support on employee performance, meaning that hypothesis 4 (H4) is supported. The better the perceived organizational support for the organization, the more it can affect employee engagement so that it can improve employee performance.

\section{Discussion}

Based on the research results that have been described, this study found several findings. First, the effect of Perceived Organizational Support on Employee Engagement is shown by the results of $Z=0.628$; $t=6,096 ; p<0.001$ indicates that there is a significant influence between perceived organizational support on employee engagement in regional public hospital employees, dr. Zainal Abidin. Perceived organizational support or perceived organizational support is defined as employees' perceptions of the organization about how much an organization appreciates the contribution and care for the welfare of its employees (Ariarni \& Afrianty, 2017; Luh et al., 2020; Mursidta, 2017; Pertiwi et al., 2019). Perceived Organizational Support can also be seen as an organizational commitment to employees (Lase et al., 2020; Mujiasih, 2015). If the organization generally appreciates the dedication and loyalty of employees as a form of employee commitment to the organization, the employees generally also pay attention to how committed the organization has to them. (Fatdina, 2015). Employees with a high level of perceived organizational support are more maximal in providing their performance so that perceived organizational support will result in remuneration in the form of a level of engagement with employees or employee 
engagement (Mufarrikhah et al., 2020; Simatupang \& Salendu, 2019). Organizational support plays a very important role in indicating the company's willingness to pay attention to and reward employee performance in helping the company succeed(Panuju \& Mangundjaya, 2018). So, Perceived organizational support will have a positive impact on employee engagement. Thus, Perceived Organizational Support is organizational support that is viewed with global conviction about the extent to which organizations assess contributions, pay attention to welfare, listen to complaints, pay attention to life and consider goals achieved, and can be trusted in treating employees fairly.

This research is in line with the results of research conducted by Alkasim \& Prahara, (2019) shows that there is a significant positive relationship between perceived organizational support and employee engagement. The acceptance of the hypothesis in this study shows the coefficient of determination (R2) of 0.375 , the perceived organizational support variable shows a $37.5 \%$ contribution to employee engagement, and the remaining $62.5 \%$ is influenced by other factors, namely job characteristics, reward \& recognition, received supervisor support. Research conducted by Mufarrikhah et al., (2020) shows that the results of perceived organizational support have a positive role in employee work engagement ( $\mathrm{F}$ value $=152.442 ; \mathrm{p}=<0.005)$. Meanwhile, the effective contribution made by perceived organizational support can predict work engagement by $33.8 \%$. This means that perceived organizational support is proven to have a role in the high and low level of employee work engagement.

Second, the influence of Perceived Organizational Support on employee performance. Based on the test results, the results show $\mathrm{Y}=0.791 ; \mathrm{t}=12,022 ; \mathrm{p}<0.001$, the results show that Perceived Organizational Support has a significant effect on employee performance. Perceived organizational support felt by employees affects behavior in carrying out their obligations and responsibilities. Perceived Organizational Support has an impact on increasing company commitment, attitudes towards work such as job satisfaction and positive mood job involvement, job performance, the desire to stay in the company, and reduce pressure at work. Perceived positive organizational support from employees will make employees work better by prioritizing commitment to goals, monitoring their behavior to ensure that what is done is correct and in accordance with the goals to be achieved, and also uses intelligence to make choices on how best to complete a task and making decisions to correct if needed is an indication of high engagement employees. Performance is intended as the level of success of the individual as a whole during a certain period in carrying out the task compared to the standard of work results, targets or targets or criteria that have been determined and have been set together (Ariarni \& Afrianty, 2017; Sufriadi, 2018).

Research conducted by Fatoni et al., (2018) shows that Perceived organizational support, employee engagement has a significant effect on employee performance, as well as Employee Engagement and organizational commitment, have a significant effect on OCB, and OCB has a significant direct effect on employee performance. Research conducted by Dai \& Qin, (2016) shows the results of the research show that: first, Perceived organizational support and employee engagement thas a significant positive correlation, perceived organizational support has a positive direct effect on employee engagement employees; second, Perceived organizational Support can also play a role in k employee engagement employees through organizational identification.

Third Effect of employee engagement on employee performance. The test results show that $\mathrm{Y}=$ $0.323 ; \mathrm{t}=2,766 ; \mathrm{p}<0.01$ ). Then the results of hypothesis testing can be concluded that employee engagement has a positive and significant effect on employee performance at the Regional General Hospital dr. Zainoel Abidin Banda Aceh. Employee engagement is an employee's enthusiasm for work that occurs because employees direct their energies to work in line with the company's strategic priorities (Afendi et al., 2020; Asih \& Dewi, 2017; Kang et al., 2020; Pringgabayu \& Kusumastuti, 2016). This spirit is formed because employees feel attached to the organization so that it has a positive potential for the organization, namely an increase in income. Factors that influence Employee Engagement include (1) Job resources which refer to the physical, social and organizational aspects of the work that allow workers to meet work demands related to their physical and mental health, (2) Salience of Job re-sources, namely how the worker deals with job demands and fulfills these demands, and (3) personal resource which is a positive self-evaluation that will relate to a person's feelings towards his or her ability to succeed in managing and giving influence the environment (Bakker et al., 2014). So, Employee Engagement is an employee's attitude and behavior at work by expressing himself in totality both physically, cognitively, affective, and emotionally. Employees find meaning in work, pride in being part of the organization where they work, working to achieve the overall vision and mission of an organization. Employees will go the extra mile and strive for the above work so that what is expected is achieved in both time and energy. In other words, with Employee Engagement, employees will show their best performance (Fajriah \& Darokah, 2016). Performance is intended as the level of success of the individual as a whole during a certain period in carrying out the task compared to the standard of work results, targets, or targets or criteria that have been determined and have been set together (Ariarni \& Afrianty, 2017; Sufriadi, 2018). 
Fourth Based on the results of the mediation test conducted by researchers, it is known that employee engagement mediates the relationship between perceived organizational support and employee performance. Based on the results of the analysis of the effect of mediation, it was found that there was an effect of mediation/mediation on employee engagement in the relationship between perceived organizational support on employee performance, meaning that hypothesis 4 (H4) is supported. The better the perceived organizational support for the organization, the more it can affect employee engagement so that it can improve employee performance. Perceived positive organizational support from employees will make employees work better by prioritizing commitment to goals, (Luh et al., 2016; Wardani \& Anwar, 2019). Engagement is the key, both a leader or an employee must strive to have smart engagement, leading to enthusiasm, motivation, and productivity, without causing fatigue. So, based on the results of the research that Perceived Organizational Support and employee engagement greatly impacted the performance of employees at the regional general hospital dr. Zainoel Abidin Banda Aceh.

\section{Conclusion}

Research and data analysis that has been carried out to employees at the Regional General Hospital dr. Zainoel Abidin Banda Aceh regarding the effect of perceived organizational support on employee engagement and its impact on performance, it can be concluded from the results of the study that Perceived Organizational Support and employee engagement greatly impact the performance of employees at the regional public hospital dr. Zainoel Abidin Banda Aceh. The higher Perceived Organizational Support will have an impact on increasing employee engagement of employees which directly affects career performance.

\section{Acknowledgement}

A big thank you to the Deputy for Strengthening Research and Development of the Ministry of Research and Technology / National Research and Innovation Agency as a research funder for the 2020 Beginner Lecturer Research (PDP) scheme and also to LPPM STIE Sabang Banda Aceh and the lecturers, colleagues, staff of RSUZA Aceh Province, and the research team who helped complete this research as expected.

\section{References}

Afendi, A., Wibowo, A., \& Wangloan, E. H. (2020). the Model of Perceived Organizational Support, Employee Engagement, Organizational Citizenship Behavior in the Environment Directorate General of Sea Transportation. International Review of Management and Marketing, 10(1), 79-83. https://doi.org/10.32479/irmm.9145

Alkasim, M. A., \& Prahara, S. A. (2019). Perceived Organizational Support Dengan Employee Engagement Pada Karyawan. Psikoislamedia, 185-194. http://dx.doi.org/10.22373/psikoislamedia.v4i2.5169

Ariarni, N., \& Afrianty, T. W. (2017). Pengaruh Perceived Organizational Support Terhadap Kinerja Karyawan Dengan Employee Engagement Sebagai Variable Intervening ( Studi pada Karyawan PT . Pos Indonesia Kota Madiun ). Jurnal Administrasi Bisnis, 50(4), 169-177. http://administrasibisnis.studentjournal.ub.ac.id/index.php/jab/article/view/2045

Asih, G. Y., \& Dewi, R. (2017). Komitmen Karyawan Ditinjau Dari Self Efficacy Dan Persepsi Dukungan Organisasi,Di Cv. Wahyu Jaya Semarang. Jurnal Dinamika Sosial Budaya, 19(1), 35. https://doi.org/10.26623/jdsb.v19i1.684

Bakker, A. B., Demerouti, E., \& Sanz-Vergel, A. I. (2014). Burnout and Work Engagement: The JDR Approach. Annual Review of Organizational Psychology and Organizational Behavior, 1, 389-411. https://doi.org/10.1146/annurev-orgpsych-031413-091235

Dai, K., \& Qin, X. (2016). Perceived Organizational Support and Employee Engagement: Based on the Research of Organizational Identification and Organizational Justice. Open Journal of Social Sciences, 04(12), 46-57. https://doi.org/10.4236/jss.2016.412005

Fajriah, N., \& Darokah, M. (2016). Pengaruh Efikasi Diri Dan Persepsi Iklim Organisasi Terhadap Kinerja Dengan Employee Engagement Sebagai Variabel Mediator Pada Karyawan Bmt Bif Yogyakarta. Humanitas, 13(1), 37. https://doi.org/10.26555/humanitas.v13i1.3841

Fatdina. (2015). Peran Dukungan Organisasi Yang Dirasakan Karyawan Sebagai Mediator Pengaruh 
Keadilan Prosedural Terhadap Perilaku Kewarganegaraan Organisasi. Jurnal Psikologi, 36(1), 1-17. https://doi.org/10.22146/jpsi.7901

Fatoni, M., Prihatini, D., \& Barokah Suryaningsih, I. (2018). The Role of OCB in Mediating The Effect of Employee Engagement and Organizational Commitment on Employee Performance: Contract vs Permanent Employees. International Journal of Scientific Research and Management, 6(08), 568579. https://doi.org/10.18535/ijsrm/v6i8.el03

Iskandar, S., \& Juhana, E. (2014). Pengaruh Kompetensi Dan Lingkungan Kerja Terhadap Kepuasan Kerja Serta Implikasinya Pada Kinerja Guru Di SDN Baros Mandiri 5 Kota Cimahi. Jurnal Ekonomi, Bisnis \& Entrepreneurship, 8(2), 86-98. http://jurnal.stiepas.ac.id/index.php/jebe/article/view/41

Kang, J. Y., Lee, M. K., Fairchild, E. M., Caubet, S. L., Peters, D. E., Beliles, G. R., \& Matti, L. K. (2020). Relationships Among Organizational Values, Employee Engagement, and Patient Satisfaction in an Academic Medical Center. Mayo Clinic Proceedings: Innovations, Quality \& Outcomes, 4(1), 8-20. https://doi.org/10.1016/j.mayocpiqo.2019.08.001

Lase, M., Manurung, Y. S., \& Akmal, M. El. (2020). Keinginan Berpindah Kerja ditinjau dari Persepsi Dukungan Organisasi Karyawan Toko Matahari Medan Fair. Journal of Education, Humaniora and Social Sciences (JEHSS), 2(3), 597-606. https://doi.org/10.34007/jehss.v2i3.120

Luh, N., Astuti, P., Putu, N., \& Harta, S. (2016). Pengaruh Work Engagement Pada Kinerja Transformasional Sebagai Pemoderasi. E-Jurnal Ekonomi Dan Bisnis Universitas Udayana, 12(5), 4057-4082. https://ojs.unud.ac.id/index.php/EEB/article/view/24128

Luh, N., Eka, P., Prastiwi, Y., Ningsih, L. K., \& Gorda, A. A. N. E. S. (2020). Perceived organizational support dan kinerja pegawai : leader member exchange sebagai mediator Perceived organizational support and employee performance: leader member exchange as a mediator. Kinerja, 17(2), 298-304. https://doi.org/http://dx.doi.org/10.29264/jkin.v17i2.7490

Mufarrikhah, J. L., Yuniardi, M. S., \& Syakarofath, N. A. (2020). Peran Perceived Organizational Support terhadap Work Engagement Karyawan. Gadjah Mada Journal of Psychology (GamaJoP), 6(2), 151164. https://doi.org/10.22146/gamajop.56396

Mujiasih, E. (2015). Hubungan Antara Persepsi Dukungan Organisasi (Perceived Organizational Support) Dengan Keterikatan Karyawan (Employee Engagement) Endah Mujiasih. Jurnal Psikologi Undip, 14(1), 40-51. https://doi.org/https://doi.org/10.14710/jpu.14.1.40-51

Mursidta, S. (2017). Pengaruh Perceived Organizational Support (Persepsi Dukungan Organisasi) Dan Kepuasan Kerja Terhadap Kinerja Karyawan Pada Pt. Varia Usaha Beton Gresik. Jurnal Ilmu $\begin{array}{lll}\text { Manajemen } & \text { (JIM), } & \text { 1-12. }\end{array}$ https://jurnalmahasiswa.unesa.ac.id/index.php/jim/article/download/18387/16763

Panuju, N. F., \& Mangundjaya, W. L. (2018). Persepsi Dukungan Organisasi dan Komitmen Afektif Organisasi: Peran Mediasi Keterikatan Karyawan pada Karyawan Pertelevisian. Psikohumaniora: Jurnal Penelitian Psikologi, 3(2), 223. https://doi.org/10.21580/pjpp.v3i2.2790

Pertiwi, L. D., Istiqomah, E., \& Zwagery, R. V. (2019). Hubungan Antara Determinasi Diri Dengan Keterikatan Kerja Pada Karyawan Pt Pelindo Iii ( Persero ) Cabang Banjarmasin the Relationship Between Self Determination Toward the Work Engagement on Employees of Pt Pelindo Iii ( Persero ) Banjarmasin Branch. Jurnal Kognisia, 2(1), 94-98. https://doi.org/https://doi.org/10.20527/jk.v2i1.1623

Pringgabayu, D., \& Kusumastuti, D. (2016). Peningkatan Keterkaitan Karyawan Melalui Sistem Rekrutmen, Desain Pekerjaan, Kompensasi dan Iklim Organisasi dengan Lingkungan Kerja Sebagai Variabel Moderasi. Bina Ekonomi, 20(2), 141-162. https://doi.org/10.26593/be.v20i2.2307.141-162

Simatupang, M. F., \& Salendu, A. (2019). Persepsi Dukungan Organisasi Sebagai Mediator Antara Keadilan Organisasi Dan Kepuasan Kerja Karyawan Di PT ABC. Jurnal Diversita, 5(2), 86-94. http://dx.doi.org/10.31289/diversita.v5i2.2696

Sufriadi, D. (2018). Peranan Kepemimpinan dalam Meningkatkan Etos Kinerja Pegawai pada Biro Tata Pemerintahan Sekretariat Daerah Provinsi Aceh. Gastrointestinal Endoscopy, 1(2), 279-288. https://doi.org/10.32877/eb.v1i2.31

Wardani, L. M. I., \& Anwar, M. S. (2019). The role of quality of work life as mediator: Psychological capital and work engagement. Humanities and Social Sciences Reviews, 7(6), 447-463. https://doi.org/10.18510/hssr.2019.7670 